\title{
Essential of audiology: screening and post- screening
}

\author{
Francesco Martines ${ }^{1 *}$, Pietro Salvago ${ }^{1}$, Salvatore Cocuzza ${ }^{2}$, Eleonora La Mattina ${ }^{3}$, Martinelli Stefano ${ }^{4}$, \\ Marianna Mucia $^{3}$, Enrico Martines ${ }^{3}$ \\ From 70th Congress of the Italian Society of Pediatrics, Joint National Meeting SIP, SICuPP, SITIP \\ Palermo, Italy. 11-14 June 2014
}

Newborn hearing screening is a type of screening test for the early detection of hearing loss. It can recognize with good accuracy newborns affected by hearing impairment allowing an early diagnosis and intervention and avoiding cognitive and linguistic deficits [1-6].

The incidence of bilateral sensorineural hearing loss (SNHL) in Sicily is 2.35 cases per 1000 newborns; this value increases to 2.95 if we consider also unilateral SNHL $[2,3]$ and to 10 cases per 1000 births among infants at risk [7-9].

A correct newborn hearing screening programme is based on different protocols depending on the presence/ absence of audiologic risk factors:

- Newborns without risk factors: [1-3]

Initial Hearing Screening (Step I): The initial screening should be performed using TransientEvoked Otoacoustic Emissions (TEOAEs) in the birth centers as close to discharge as possible, preferably 12 hours or more after birth. It is recommended that an infant be referred for a re-screening (step 2) if s/he does not pass the initial screening or results cannot be obtained in one or both ears.

Re-screening (Step II): The re-screening should be performed in a second level center using TEOAEs and Automated Auditory Brainstem Response (AABR). If an infant does not pass the re-screening or if results cannot be obtained in one or both ears, $\mathrm{s} /$ he shall be referred to the regional third level center for diagnostic audiological evaluation.

- Newborns with risk factors (JCIH 2007) [7-10]

* Correspondence: francesco.martines@unipa.it

${ }^{1}$ Università degli Studi di Palermo, Dipartimento di Biomedicina Sperimentale e Neuroscienze Cliniche, (BioNeC), Sezione di Otorinolaringoiatria. Via del Vespro, 129 - 90127 Palermo, Italy

Full list of author information is available at the end of the article
Initial Hearing Screening (Step I): The Initial Hearing Screening should be performed in a second level center using TEOAEs and AABR. If an infant does not pass the initial screening or if results cannot be obtained in one or both ears, $\mathrm{s} / \mathrm{he}$ shall be referred to the regional third level center for diagnostic audiological evaluation.

\section{Screening variables}

Actually TEOAEs have a sensitivity of $100 \%$ and a specificity of about $70-95 \%$. A higher TEOAEs specificity value depends on $[1,2,11]$ :

- Timing of TEOAEs recording

- Trained and qualified personnel

- PASS/REFER criteria

\section{Limitations of screening}

Audiologic screening does not identify:

- Post-natal SNHL (prelingual or perilingual), mainly related to genetic causes $[12,13]$

- ANSD (Auditory Neuropathy Spectrum Disorder): the main risk factors associated to ANSD are severe jaundice, prematurity, respiratory distress, ototoxic drugs (used to treat neonatal infections), genetic mutations (e.g. OTOF gene). The diagnosis of ANSD is usually based on the combination of absent or abnormal ABR with normal TEOAESs and/or cochlear microphonics $(\mathrm{CM})[14]$.

\section{Authors' details}

${ }^{1}$ Università degli Studi di Palermo, Dipartimento di Biomedicina Sperimentale e Neuroscienze Cliniche, (BioNeC), Sezione di Otorinolaringoiatria. Via del Vespro, 129 - 90127 Palermo, Italy. ${ }^{2}$ Università degli Studi di Catania, Dipartimento di Specialità Medico-Chirurgiche, Clinica Otorinolaringoiatrica, Via Santa Sofia, 68, 95125 Catania, Italy. ${ }^{3}$ Università degli Studi di Palermo, 
Dipartimento di Biopatologia e Biotecnologie Mediche e Forensi (Di.Bi.Me.F.), Sezione di Audiologia. Via del Vespro, $129-90127$ Palermo, Italy. ${ }^{4}$ Azienda Ospedaliera 'Ospedale Niguarda Cà Granda' - U.O.C. Neonatologia e Terapia Intensiva Neonatale. Piazza Ospedale Maggiore, 3 - 20162 Milano, Italy.

Published: 11 August 2014

\section{References}

1. Ballacchino A, Mucia M, Cocuzza S, Ferrara S, Martines E, Salvago P, Sireci F, Martines F: Newborn hearing screening in Sicily: Lesson learned. Acta Medica Mediterranea 2013, 29:731-734.

2. Martines F, Porrello M, Ferrara M, Martines M, Martines E: Newborn hearing screening project using transient evoked otoacoustic emissions: Western Sicily experience. Int J Pediatr Otorhinolaryngol 2007, 71:107-112.

3. Martines F, Bentivegna D, Ciprì S, Costantino C, Marchese D, Martines E: On the threshold of effective well infant nursery hearing screening in Western Sicily. Int J Pediatr Otorhinolaryngol 2012, 76:423-427.

4. Maggio M, Maggio O, Mucia M, Martines F, Carmuco A, Noto G, Puccio R: The scholastic integration process of the impaired child in the province of Palermo: a cognitive survey. Acta Medica Mediterranea 2006, 22:159-162.

5. Maggio M, Martines F, Mucia M, Maggio O: A multifactorial pattern for the understanding of the psychological development of the child with impaired hearing and its clinical-therapeutic implications. Acta Medica Mediterranea 2006, 22:41-44.

6. Martines F, Martines E, Ballacchino A, Salvago P: Speech perception outcomes after cochlear implantation in prelingually deaf infants: The Western Sicily experience. Int J Pediatr Otorhinolaryngol 2013, 77:707-713.

7. Martines F, Salvago P, Bentivegna D, Bartolone A, Dispenza F, Martines E: Audiologic profile of infants at risk: Experience of a Western Sicily tertiary care centre. Int J Pediatr Otorhinolaryngol 2012, 76:1285-1291.

8. Salvago P, Martines E, Martines F: Prevalence and risk factors for sensorineural hearing loss: Western Sicily overview. Eur Arch Otorhinolaryngol 2013, 270:3049-56.

9. Martines F, Martines E, Mucia M, Sciacca V, Salvago P: Prelingual sensorineural hearing loss and infants at risk: Western Sicily report. Int J Pediatr Otorhinolaryngol 2013, 77:513-518.

10. American Academy of Pediatrics, Joint Committee on Infant Hearing: Year 2007 position statement: principles and guidelines for early hearing detection and intervention programs. Pediatrics 2007, 120:898-921.

11. Bentivegna D, Salvago P, Agrifoglio M, Ballacchino A, Ferrara S, Mucia M, Sireci F, Martines F: The linkage between upper respiratory tract infections and otitis media: evidence of the 'united airways concept. Acta Medica Mediterranea 2012, 28:287-290.

12. Bartolotta C, Salvago P, Cocuzza S, Fabiano C, Sammarco P, Martines F: Identification of D179H, a novel missense GJB2 mutation in a Western Sicily family. Eur Arch Otorhinolaryngol 2014, 271:1457-67.

13. Martines F, Salvago P, Bartolotta C, Cocuzza S, Fabiano C, Ferrara S, La Mattina E, Mucia M, Sammarco P, Sireci F, Martines E: A genotypephenotype correlation in Sicilian patients with GJB2 biallelic mutations. Eur Arch Otorhinolaryngol 2014, DOI 10.1007/s00405-014-2970-1.

14. Martines F, Salvago P: Hyperbilirubinemia, Auditory Neuropathy and Prelingually Deafness: Evidence Linking. In Neonatal Care: New Research Novinka; Fabian Koubek \& Junica Linser 2013, 79-97.

doi:10.1186/1824-7288-40-S1-A55

Cite this article as: Martines et al.: Essential of audiology: screening and post-screening. Italian Journal of Pediatrics 2014 40(Suppl 1):A55.

\section{Submit your next manuscript to BioMed Central and take full advantage of:}

- Convenient online submission

- Thorough peer review

- No space constraints or color figure charges

- Immediate publication on acceptance

- Inclusion in PubMed, CAS, Scopus and Google Scholar

- Research which is freely available for redistribution

Submit your manuscript at www.biomedcentral.com/submit
Biomed Central 